\title{
Application of semi-quantitative and quantitative methods for the selection of cellulolytic filamentous fungi isolated from pulp mill materials
}

\author{
Beata Miklaszewska, Dorota Macko, Grzegorz KŁosowski *, Dawid Mikulski \\ Department of Biotechnology, Kazimierz Wielki University, Bydgoszcz, Poland
}

\begin{abstract}
A semi-quantitative method (the enzymatic activity index, EI) and a quantitative method (the amount of reducing sugars, RS) have been used for selecting cellulolytic microorganisms. The analysis was performed with 90 isolates of filamentous fungi selected from pulp mill materials. In both methods $1 \%$ low viscosity carboxymethylcellulose (1\% CMC 1.v.) was used as a substrate. For $n=90$, no correlation between the parameters has been found. A further analysis was carried out for 12 selected isolates: 6 with the highest RS values and 6 with the highest EI values. For the chosen fungi, also cultivated on $1 \% \mathrm{CMC}$ l.v. medium, the following parameters have been determined: the total cellulase activity (filter paper assay, FPase), endoglucanase (CMCase) activity, $\beta$-glucosidase (CBase) activity, and the changes in the culture medium viscosity (DV). The statistical analysis revealed a negative, moderately marked correlation between EI and RS and clearly marked positive correlations for two pairs: RS-FPase and DV-FPase. A high positive correlation between RS and DV has also been observed. Correlations between EI, RS, DV, CMCase, and CBase activities were weak. It was shown that the quantitative parameter RS is more suitable than EI for the evaluation of the total cellulolytic activity of filamentous fungi. The application of CMC as the only source of carbon in the culture media and the subsequent determination of EI or RS has failed to provide the means for selecting fungi with a high endoglucanase (CMCase) activity.
\end{abstract}

Key words: cellulases, filamentous fungi, selection methods, enzymatic activity index (EI), pulp mill materials

\section{Introduction}

Cellulases are a group of hydrolases (EC 3) capable of hydrolyzing $\beta$-1,4-glycosidic linkages in cellulose. The group comprises endoglucanases (1,4- $\beta$-D-glucan glucanohydrolases, EC 3.2.1.4, EGs), exoglucanases (cellobiohydrolase I and II, 1,4- $\beta$-D-glucan cellobiohydrolase, EC 3.2.1.91, CBHs), and $\beta$-glucosidases. Endoglucanases randomly cleave linkages inside the cellulose chain, mainly in the amorphous region, releasing oligosaccharides of various lengths. Exoglucanases hydrolyze linkages acting from reducing and non-reducing ends of cellulose and oligosaccharide chains and release mainly cellobiose. $\beta$-glucosidases ( $\beta$-D-glucosidase glucohydrolase, EC 3.2.1.21, BGL) catalyze the hydrolysis of cellobiose to glucose. An effective cellulose hydrolysis is determined by a cooperation of the abovementioned three enzyme types (Pérez and Monoz-Moraleda, 2011; Shu- angqi et al., 2011). However, according to Zhang et al. (2006), the most important role in the process have endoglucanases (EGs) and exoglucanases (CBHs).

The studies on the acquisition, characteristics, and application of cellulolytic enzymes are being vigorously pursued. The research is important not only from the theoretical point of view, but also from the practical point of view. Cellulolytic enzymes are widely applied in the industry, e.g., for food, animal feed, pulp, paper, detergent, textile, art silk, fruit juice, wine, and beer production (Bhat, 2000; Zhang et al., 2006; Kuhad et al., 2011). Nowadays, the most challenging issue is the development of technologies enabling hydrolysis of natural lignocellulosic biomass to produce glucose which can be used for the production of methanol (Ishikawa and Saka, 2001), butanol, amino acids, SCP, and ethanol fuel (Sun and Cheng, 2002; Alvira et al., 2010). 
Studies on the acquisition of new enzymatic proteins showing cellulase activity are of utmost importance because of the high cost of the enzymes needed for the hydrolysis of lignocellulosic materials (Cherry and Fidantsef 2003; Zhang et al. 2006).

The aerobic decomposition of cellulose is mainly carried out by filamentous fungi: Ascomycota (Chaetomium), Basidiomycota (Coriolus, Phanerochaete, Poria), and anamorphs of Aspergillus, Cladosporium, Fusarium, Geotrichum, Penicillium, and Trichoderma (Pérez and Monoz-Moraleda, 2011). The fungal biomass can be easily separated from the culture filtrate which contains the secreted extracellular enzymes. Thanks to this feature, fungi gained an advantage over the bacteria in the process of industrial cellulase production.

The acquisition of strains of filamentous fungi producing cellulolytic enzymes is a subject of extensive studies. Strategies that are frequently used for selection of cellulolytic microorganisms involve the application of cellulose as the only source of carbon in the growing media. Subsequent analysis includes 1) checking for the presence of microbial colonies and 2) estimating the activity of cellulolytic enzymes by measuring the enzymatic index (EI). The EI is calculated as the ratio of the diameter of the cellulose hydrolysis zone marked by Congo red to the diameter of the colony growing on a given cellulose medium. Congo red binds strongly to long polysaccharide chains which contain $\beta$-(1-4) D-glucopyranose units, $\beta$-(1-3) D-glucanes, and, probably, hemicellulosic galactoglucomannans. The dye is confirmed to be a sensitive means for detecting anaerobic bacteria which produce cellulolytic enzymes (Teather and Wood, 1982).

Estimation of EI is a semiquantitative, relatively inexpensive method used for screening a large number of samples, but of limited precision, e.g., enzyme activities differing by less than two-fold are difficult to discern (Zhang et al., 2006). On the other hand, quantitative determination of the enzymatic activity is costlier and time consuming. Revealing a correlation between the two methods is crucial in the process of selection of microorganisms that synthesize cellulases. The results of studies by various research groups have not yet provided any basis for unequivocal evaluation of the abovementioned correlation.

Selection of filamentous fungi consists of a few stages. At the first stage, the isolates that can grow on a medium with cellulose as the only source of carbon are preselected (Florencio et al., 2012). At the second stage, the isolates with no cellulose hydrolysis zone around the colony (then EI values cannot be calculated) (Jahangeer et al., 2005; Goldbeck et al., 2012) as well as those whose $\mathrm{EI}$ is below a predefined value are rejected. Damaso et al. (2012) set the threshold to 1.0, Florencio et al. (2012) to 1.5, and Lopes et al. (2011) to 2.5. At this stage of semiquantitative appraisal, some Trichoderma species with no EI determined but with the highest EG activity can be omitted (Ruegger and Tauk-Tornisielo, 2004). The third stage involves only 7-15 isolates cultivated under submerged fermentation $(\mathrm{SmF})$ or solid-state fermentation (SSF), so that the culture filtrate with protein mixture can be obtained. At this stage, only few samples are subjected to a quantitative evaluation. Sazci et al. (1986) and Florencio et al. (2012) showed a correlation between the results obtained by semiquantitative and quantitative methods, but Goldbeck et al. (2012) and Damaso et al. (2012) pointed out that EI could not discern between isolates with different cellulase activities.

In the present work, the application of $1 \%$ low viscosity carboxymethylcellulose (CMC l.v.) was proposed to unify the measurement conditions for both semiquantitative and quantitative methods to reveal correlations between various parameters describing cellulolytic activity of the analyzed fungi.

The aim of the study was to determine the correlation between a semiquantitative method (EI values) and quantitative parameters, such as the amount of reducing sugars and the enzymatic activity, which were estimated for the media with cellulose as the only source of carbon for microorganisms. The obtained results were used for selection of cellulolytic filamentous fungi isolated from pulp mill materials.

\section{Materials and methods}

\section{Isolates of filamentous fungi}

Studies were carried out using 90 isolates of filamentous fungi obtained from pulp mill materials, such as wood chips, waste paper, and industrial cellulose. The identification of the species was carried on selective media, according to the methods of Fassatiova (1983), Samson and Frisvad (2004), and Crous et al. (2009). All isolates were stored on sterile soil at $4{ }^{\circ} \mathrm{C}$ (Kwaśna et al., 1991) in a culture bank at the Department of Biotechnology, Kazimierz Wielki University, Bydgoszcz, Poland. 


\section{Screening step of 90 fungal isolates based on reducing sugar release}

Filamentous fungi $(n=90)$ were grown in $50 \mathrm{ml}$ of Vogel's liquid medium, containing (w/v): $1.0 \%$ low viscosity carboxymethylcellulose, $0.5 \%$ trisodium citrate, $0.5 \%$ $\mathrm{KH}_{2} \mathrm{PO}_{4}, 0.2 \% \mathrm{NH}_{4} \mathrm{NO}_{3}, 0.4 \%\left(\mathrm{NH}_{4}\right)_{2} \mathrm{SO}_{4}, 0.02 \% \mathrm{MgSO}_{4}$, $0.1 \%$ peptone, $0.2 \%$ yeast extract, $1.5 \%$ agar, and $\mathrm{pH} 5.5$ (Ahmed et al., 2009). The inoculum of filamentous fungi was $5 \mathrm{ml}$ prepared as a spore suspension approx. $1 \times 10^{7} / \mathrm{ml}$ obtained by washing off the cultures from an SNA medium containing (w/v): $0.02 \%$ glucose, $0.02 \%$ sucrose, $\quad 0.05 \% \quad \mathrm{KCl}, \quad 0.05 \% \quad \mathrm{MgSO}_{4} \cdot 7 \mathrm{H}_{2} \mathrm{O}, \quad 0.1 \%$ $\mathrm{KH}_{2} \mathrm{PO}_{4} \cdot \mathrm{H}_{2} \mathrm{O}, 0.1 \% \mathrm{KNO}_{3}$, and $1.5 \%$ agar (Kwaśna et al., 1991), where they grew for 7 days at $28^{\circ} \mathrm{C}$. After 5-day incubation of the fungi in a liquid medium (submerged fermentation, $\mathrm{SmF}$ ) at $28^{\circ} \mathrm{C}$, the amount of reducing sugars $(\mathrm{mg} / \mathrm{g}$ of $\mathrm{CMC})$ in the cell-free culture supernatant was calculated, according to the procedure described by Miller (1959).

\section{Screening steps of 90 fungal isolates using the enzymatic activity index (EI)}

The Congo red test was conducted for all 90 isolates using an agar medium prepared according to Vogel's formula with $1.0 \% \mathrm{CMC}$ (the composition as given earlier). One full loop of mycelium from each culture growing for 7-10 days on an SNA medium was inoculated into the center of Petri dishes with the agar medium. Tests were performed in triplicate. Incubation was carried out for 4 days, at $28^{\circ} \mathrm{C}$. The $\mathrm{CMC}$ hydrolysis zones were visualized by submerging the agar plates in the Congo red solution $(1 \mathrm{mg} / \mathrm{ml})$ for $30 \mathrm{~min}$. After the dye solution was removed and the plates were flooded with $1 \mathrm{M} \mathrm{NaCl}$ for 10 min (Teather and Wood, 1982; Sazci et al., 1986), measurements of colony diameters and hydrolysis zones (measured with precision to $1 \mathrm{~mm}$ ) were immediately performed. The enzymatic activity index (EI) for colonies growing on the agar medium, containing cellulose as the only source of carbon, was computed as the ratio of $\mathrm{CMC}$ hydrolysis zone diameter to the colony diameter.

\section{Screening of selected 12 isolates}

For further analysis, 12 out of 90 isolates were selected. Six of them had the highest RS values, while grown under submerged fermentation with $1 \% \mathrm{CMC}$ (group 1: max RS). Six isolates had the highest EI values, while grown on solid state media with CMC (group 2: max EI). One isolate, called Penicillium funiculosum 1.6, belonged to both groups. Filamentous fungi $(n=12)$ were grown in a liquid medium with the addition of 1.0\% CMC. For selected isolates the following parameters were determined in the cell-free culture supernatant: decrease in the viscosity of $\mathrm{CMC}$ solution (DV), the amount of proteins $(\mathrm{mg} / \mathrm{ml})$, the amount of reducing sugars ( $\mathrm{mg} / \mathrm{g}$ of cellulose), the total cellulolytic activity (FPase), endoglucanase activity (CMCase), and cellobiase activity (CBase). Each enzyme activity was expressed as $\mathrm{IU} / \mathrm{ml}$ of undiluted culture supernatant and $\mathrm{IU} / \mathrm{mg}$ of protein. One unit (IU) of enzymatic activity was defined as the amount of enzyme that released $1 \mu \mathrm{mol}$ of glucose per min from a cellulose substrate, under the conditions described by Ghose (1987).

\section{Protein concentration determination}

The protein concentration was determined with the Bradford method using Coomassie Blue G-250 (Bradford, 1976). Protein concentrations in the samples were calculated from the standard curve which was made using BSA (Fluka) concentrations ranging from 50 to $400 \mu \mathrm{g} / \mathrm{ml}$.

\section{Decrease in the viscosity of 1\% CMC solution (DV) estimation}

Measurements of endoglucanase activity, based on the changes in the viscosity of the cell-free culture supernatant, were done with reference to $1.0 \%$ solution of CMC. The viscosity was measured with Ubbelohde viscometer at $30^{\circ} \mathrm{C}$ (a modified method according to Russel et al., 2005). The decrease in the viscosity of the culture extract (DV\%) was computed as

$$
\mathrm{DV}(\%)=\left(T_{\mathrm{k}}-T_{\mathrm{p}}\right) / T_{\mathrm{k}} \times 100
$$

where,

$T_{\mathrm{k}}$ - the efflux time of a reference liquid through the viscometer capillary (s),

$T_{\mathrm{p}}$ - the efflux time of the analyzed fluid through the viscometer capillary (s).

\section{Enzymatic activities}

All enzymatic activities were measured in the cellfree culture supernatant according to IUPAC recommendations (Ghose, 1987). The total cellulolytic activity was 
Table 1. The parameter of EI (Congo red test) and concentration of RS (SmF with 1.0\% CMC) values of isolates of cellulolytic filamentous fungi $(n=90)$

\begin{tabular}{|c|c|c|c|}
\hline Taxon & $\begin{array}{l}\text { Number } \\
\text { of isolates }\end{array}$ & $\begin{array}{l}\text { EI average } \\
{\text { (range) })^{2}}^{\text {En }}\end{array}$ & $\begin{array}{l}\mathrm{RS}(\mathrm{mg} / \mathrm{g} \text { of } \mathrm{CMC})^{1} \text { average } \\
(\text { range })^{2}\end{array}$ \\
\hline Penicillium spp. & 26 & $\begin{array}{c}1.20 \\
(0.00-3.17) \\
\end{array}$ & $\begin{array}{c}42 \\
(30-64) \\
\end{array}$ \\
\hline Trichoderma spp. & 16 & $\begin{array}{c}0.67 \\
(0.00-1.71) \\
\end{array}$ & $\begin{array}{c}44 \\
(29-77) \\
\end{array}$ \\
\hline A. fumigatus & 15 & $\begin{array}{c}1.37 \\
(0.00-3.70)\end{array}$ & $\begin{array}{c}40 \\
(27-54)\end{array}$ \\
\hline A. nidulans & 8 & $\begin{array}{c}1.94 \\
(1.00-4.04)\end{array}$ & $\begin{array}{c}42 \\
(30-67) \\
\end{array}$ \\
\hline Acremonium spp. & 7 & $\begin{array}{c}1.13 \\
(1.06-1.18)\end{array}$ & $\begin{array}{c}33 \\
(30-40)\end{array}$ \\
\hline A. flavus & 3 & $\begin{array}{c}1.10 \\
(1.04-1.15) \\
\end{array}$ & $\begin{array}{c}40 \\
(34-46) \\
\end{array}$ \\
\hline Absidia spp. & 3 & $\begin{array}{c}0.73 \\
(0.00-1.29) \\
\end{array}$ & $\begin{array}{c}31 \\
(27-37) \\
\end{array}$ \\
\hline Fusarium spp. & 2 & $\begin{array}{c}1.09 \\
(0.09-1.09) \\
\end{array}$ & $\begin{array}{c}43 \\
(34-52) \\
\end{array}$ \\
\hline F. moniliforme & 2 & $\begin{array}{c}0.98 \\
(0.95-1.00)\end{array}$ & $\begin{array}{c}30 \\
(29-31)\end{array}$ \\
\hline Paecilomyces spp. & 2 & $\begin{array}{c}0.55 \\
(0.00-1.10) \\
\end{array}$ & $\begin{array}{c}33 \\
(31-35) \\
\end{array}$ \\
\hline Aspergillus spp. & 1 & 0.95 & 30 \\
\hline A. sydowii & 1 & 1.95 & 30 \\
\hline Mycelia sterilia & 4 & $\begin{array}{c}2.14 \\
(1.02-4.00) \\
\end{array}$ & $\begin{array}{c}31 \\
(27-36) \\
\end{array}$ \\
\hline
\end{tabular}

${ }^{1}$ In cell-free culture supernatant; ${ }^{2}$ Minimum and maximum value; Identified species of fungi belonging to the genera: Trichoderma spp. (T. harzianum, T. koningii, T. viride), Penicillium spp. (P. aurantiogriseum, P. brevicompactum, $P$. chrysogenum, $P$. crustosum, $P$. funiculosum, $P$. janczewskii, $P$. janthinellum, $P$. palitans, $P$. solitum ) and Acremonium spp. (A. strictum)

measured by filter paper assay (FPase) with Whatman No. 1 filter paper (approx. $50 \mathrm{mg}$ ) as the substrate. Endoglucanase activity (CMCase) was measured with low viscosity carboxymethylcellulose sodium salt from Sigma-Aldrich as the substrate $(2 \% \mathrm{CMC}$ in citrate buffer, $\mathrm{pH} 4.8$ ). The amount of reducing sugars was determined using the DNS method. $\beta$-glucosidase activity (CBase) was measured as cellobiase activity, using D-(+)cellobiose from Fluka (15.0 mmol of cellobiose in citrate buffer, $\mathrm{pH}=4.8)$. Glucose was determined by glucose oxidase-peroxidase-o-dianisidine (GOPOD) method (Huggett and Nixon, 1955).

\section{Statistical analysis}

The statistical analysis was carried out with Statistica software, version 10.0. A correlation analysis was performed to reveal the relationships between EI, RS, FPase, CMCase, CBase, and DV. Tests were applied at the significance level $\alpha<0.05$. The data originated from three independent experiments.

\section{Results}

\section{Relationships between EI and RS for 90 isolates}

Studies were carried out on 90 isolates of different filamentous fungi from pulp mill materials, isolated regardless of the species and materials, using a solidified medium containing cellulose as the only source of carbon. Amongst filamentous fungi, the one that has been isolated most often was Penicillium (26 isolates), followed by Trichoderma (16 isolates), and Aspergillus fumigatus (15 isolates) - Table 1. 


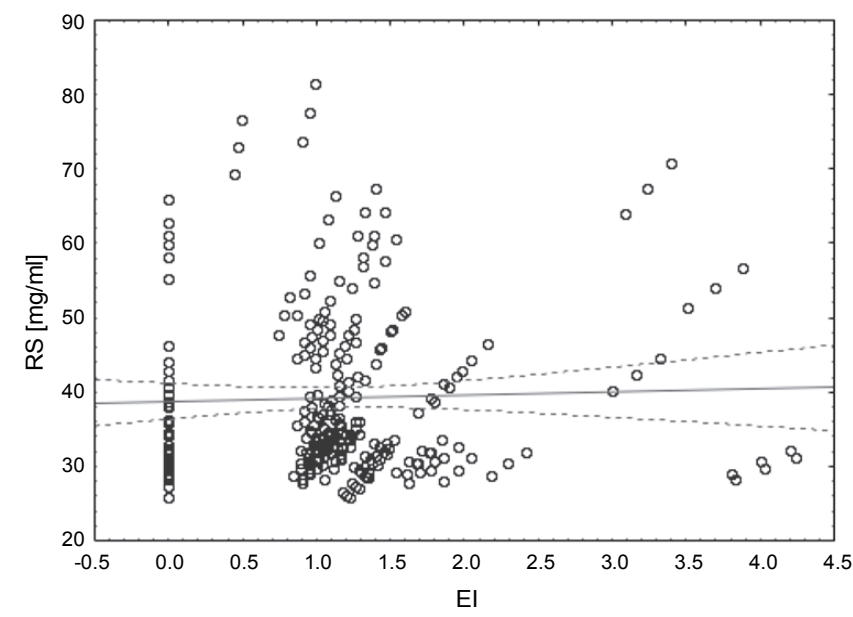

Fig. 1. EI vs. RS (mg/ml) for analyzed isolates of filamentous fungi $(n=90)$

The values of EI and RS for all 90 isolates were determined. The activity of cellulolytic enzymes (mainly endoglucanase) produced by colony-forming filamentous fungi was reflected in the EI values that characterized the $\mathrm{CMC}$ hydrolysis degree. The values determined for each taxon varied over a wide interval. For example, for Penicilium spp. the EI values from 0.0 to 3.17 were reported. Therefore, the EI can be regarded as an individual feature of a given isolate.

For as many as $48.9 \%$ of the isolates, the EI values fell into the interval 1.0-1.5. About 14 out of 90 isolates (15.5\%) had the EI value of 0.0 , which means that despite the proper growth of the colony no bright zone indicating the cellulose hydrolysis could be determined. This could be a result of short incubation time (4 days) chosen to compare the parameters of slow-and fastgrowing fungi. Two isolates reached the EI values from 4.0 to 4.5 . They were an unidentified species 1.62 $(\mathrm{EI}=4.00)$ and Aspergillus nidulans $1.7(\mathrm{EI}=4.04)$.

Maximum RS values reported for Trichoderma sp. isolates 1.12 and 2.50 were 77 and $73 \mathrm{mg} / \mathrm{g}$ of CMC, respectively, which accounted for $2 \%$ of the isolates. For most isolates (53\%), the RS values in the culture media belonged to the interval $30-40 \mathrm{mg} / \mathrm{g}$ of CMC (Table 1). A correlation analysis between EI and the amount of RS $(\mathrm{mg} / \mathrm{ml}$ of culture extract), carried out for all 90 isolates, revealed no statistical relationship ( $r=0.028$; Fig. 1).

\section{Relationships between EI, RS, DV, and enzymatic activities for 12 selected isolates}

For further analysis, 12 out of 90 isolates were selected and it was also divided into two groups. Fungi from group 1 with maximum RS had a higher mean RS value, higher average decrease in the viscosity of $\mathrm{CMC}$ solution (DV) in the culture extract, and lower EI. Only one isolate called $P$. funiculosum 1.6 counted in both groups, reached a high EI value of 3.10 and high RS value of $67 \mathrm{mg} / \mathrm{g}$ of CMC (Table 2a).

In this study, the activities of FPase, CMCase, and CBase have been evaluated for a selected group of filamentous fungi. The maximum activity values expressed as $\mathrm{IU} / \mathrm{ml}$ and $\mathrm{IU} / \mathrm{mg}$ of protein for 12 isolates were compared. The highest CMCase and FPase activities were observed in group 1 . The highest CMCase activity was observed for Trichoderma harzianum isolate 1.12 in group 1 , which reached the values $0.197 \mathrm{IU} / \mathrm{ml}$ and $1.955 \mathrm{IU} / \mathrm{mg}$ of protein by culturing on a medium with carboxymethylcellulose (Table $2 \mathrm{~b}$ ). The highest FPase activity was achieved by isolate Trichoderma koningii 2.50 , which reached the values of $0.031 \mathrm{IU} / \mathrm{ml}$ and $0.301 \mathrm{IU} / \mathrm{mg}$ of protein. CBase activities were very low and did not differ significantly (Table $2 b$ ).

A correlation analysis for the physicochemical parameters and enzyme activities marked for the 12 different selected species of fungi was also carried out. A negative average correlation between EI and FPase activity $(r=-0.342)$ was observed. RS and DV were positively correlated with FPase activity, $r$ values were 0.574 and 0.553, respectively (Fig. 2). RS and DV were also positively correlated: $r=0.779$. EI, RS, and DV were not correlated with neither CMCase nor CBase activities (Table 3).

\section{Discussion}

\section{Application of CMC as a substrate}

To compare semiquantitative (EI) and quantitative methods, in this study all experiments were carried out with the use of same substrate, i.e., low viscosity carboxymethyl cellulose (CMC) sodium salt. A drawback to the CMC application is that it is recommended for determination of endoglucanase (EG) activity rather than for all cellulases. On the other hand, the advantage of this method is that endoglucanse activity can be estimated using many parameters, such as the cellulose liquid viscosity, the amount of reducing sugars (RS), or the hydrolysis degree (EI). A large number of carboxymethyl functional groups (the degree of substitution: 0.65-0.90) suppresses the exoglucanase (EXG) activity which could 
Table 2a. The parameters of EI, concentration of RS and changes of the viscosity aqueous solutions of CMC (DV) of selected isolates of cellulolytic filamentous fungi $(n=12)$ : group 1 (max RS) and group 2 (max EI)

\begin{tabular}{|c|c|c|c|}
\hline Isolate & $\mathrm{EI}$ & $\begin{array}{c}\mathrm{RS} \\
(\mathrm{mg} / \mathrm{g} \text { of } \mathrm{CMC})\end{array}$ & $\begin{array}{l}\text { DV } \\
(\%)\end{array}$ \\
\hline \multicolumn{4}{|c|}{ Group 1} \\
\hline T. harzianum 1.12 & $1.36^{\mathrm{a}} \pm 0.18$ & $77^{\mathrm{d}} \pm 4$ & $57.39^{\mathrm{a}} \pm 2.42$ \\
\hline T. koningii 2.50 & $1.07^{\mathrm{a}} \pm 0.03$ & $73^{\mathrm{e}} \pm 5$ & $62.91^{\mathrm{b}} \pm 0.33$ \\
\hline P. funiculosum 1.6 & $3.10^{\mathrm{b}} \pm 0.21$ & $67^{\mathrm{a}} \pm 4$ & $48.37^{\mathrm{c}} \pm 1.77$ \\
\hline Penicillium spp. 2.33 & $1.83^{\mathrm{a}} \pm 0.17$ & $64^{\mathrm{ab}} \pm 7$ & $55.13^{\mathrm{a}} \pm 1.84$ \\
\hline A. nidulans 1.13 & $1.41^{\mathrm{a}} \pm 0.26$ & $63^{\mathrm{bc}} \pm 4$ & $54.75^{\mathrm{a}} \pm 0.23$ \\
\hline T. koningii 2.47 & $0.91^{\mathrm{a}} \pm 0.00$ & $63^{\mathrm{bc}} \pm 6$ & $57.16^{\mathrm{a}} \pm 2.23$ \\
\hline Penicillium spp. 2.29 & $1.63^{\mathrm{a}} \pm 0.13$ & $61^{\mathrm{c}} \pm 8$ & $58.56^{\mathrm{ab}} \pm 2.43$ \\
\hline Average & 1.61 & 67.10 & 56.32 \\
\hline \multicolumn{4}{|c|}{ Group 2} \\
\hline A. nidulans 1.7 & $4.04^{\mathrm{a}} \pm 0.21$ & $30^{\mathrm{d}} \pm 3$ & $40.51^{\mathrm{b}} \pm 2.08$ \\
\hline X 1.62 & $4.04^{\mathrm{a}} \pm 0.22$ & $31^{\mathrm{d}} \pm 4$ & $38.70^{\mathrm{b}} \pm 1.25$ \\
\hline A. fumigatus 2.20 & $3.15^{\mathrm{d}} \pm 0.05$ & $54^{\mathrm{b}} \pm 6$ & $55.52^{\mathrm{c}} \pm 1.78$ \\
\hline P. funiculosum 1.6 & $3.10^{c} \pm 0.21$ & $67^{\mathrm{a}} \pm 4$ & $48.37^{\mathrm{a}} \pm 1.77$ \\
\hline Penicillium spp. 2.37 & $2.30^{\mathrm{e}} \pm 0.01$ & $30^{\mathrm{d}} \pm 3$ & $55.67^{\mathrm{c}} \pm 1.00$ \\
\hline A. nidulans 1.28 & $3.33^{\mathrm{b}} \pm 0.53$ & $44^{\mathrm{c}} \pm 4$ & $53.10^{\mathrm{ac}} \pm 3.86$ \\
\hline Average & 3.33 & 42.80 & 48.64 \\
\hline
\end{tabular}

The mean values given in columns with different letter index are significantly different ( $\alpha$ $<0.05$ ); Group 1 - selected isolates which had the highest RS values while grown under submerged fermentation $(\mathrm{SmF})$ with 1.0\% CMC; Group 2 - selected isolates which had the highest EI values while grown on solid state media with CMC; Significant differences were determined separately for group 1 and group $2 ; \mathrm{X}$ - unidentified fungus

affect either the RS amount or the hydrolysis degree (Zhang et al., 2006).

For EI determination, Damaso et al. (2012) and Goldbeck et al. (2012) used celluloses other than CMC, e.g., microcrystalline cellulose: Avicel or Servacel. For cellulase activity determination, at the next selection stages, various cellulose types were applied: Servacel (Goldbeck et al., 2012); Whatman No. 1 filter paper (Ruegger and Tauk-Tornisielo, 2004; Jahangeer et al., 2005; Florencio et al., 2012); and wheat bran (Ruegger and Tauk-Tornisielo, 2004; Damaso et al., 2012; Florencio et al., 2012). Application of cellulose with different physicochemical properties can affect the activity of cellulases. Our results show that despite the application of $\mathrm{CMC}$ for the determination of quantitative parameters, both RS and EI values are correlated with the total cellulolytic activity (FPase) but there is no correlation between those parameters and the CMCase activity (Table 3). We therefore can conclude that the applica- tion of CMC as a substrate is useful in the selection process.

\section{Correlation between semiquantitative and quantitative methods for 90 isolates}

The semiquantitative method (EI) and quantitative method (RS) were used as tools for the selection of cellulolytic fungi. Revealing a correlation between the two methods is crucial in the process of selection of microorganisms that synthesize cellulases. The results of various research groups did not give a basis for unequivocal evaluation of the above-mentioned correlation. For example, Ruegger and Tauk-Tornisielo (2004) determined EI values, as well as CMCase and FPase activities, for 80 isolates of various filamentous fungi. The authors conclude that the results they obtained did not provide sufficient evidence to determine the strains as better or weaker producers of cellulases. For example, FPase and CMCase activities for Penicilium spp. with 
Table 2b. Cellulase activity of enzymes secreted by selected isolates of filamentous fungi: group 1 (max RS) and group 2 (max EI) in the SmF with $1.0 \% \mathrm{CMC}$

\begin{tabular}{|c|c|c|c|}
\hline Isolate & $\begin{array}{c}\text { CMCase } \\
\text { (IU/ml) } \\
\text { (IU/mg of protein) }\end{array}$ & $\begin{array}{c}\text { FPase } \\
(\mathrm{IU} / \mathrm{ml}) \\
(\mathrm{IU} / \mathrm{mg} \text { of protein })\end{array}$ & $\begin{array}{c}\text { CBase } \\
(\mathrm{IU} / \mathrm{ml}) \\
(\mathrm{IU} / \mathrm{mg} \text { of protein })\end{array}$ \\
\hline \multicolumn{4}{|c|}{ Group 1} \\
\hline T. harzianum 1.12 & $\begin{array}{c}0.197^{\mathrm{e}} \\
(1.955)^{\mathrm{B}}\end{array}$ & $\begin{array}{c}0.023^{\mathrm{b}} \\
(0.239)^{\mathrm{BD}}\end{array}$ & $\begin{array}{c}0.001^{\mathrm{a}} \\
(0.003)^{\mathrm{A}}\end{array}$ \\
\hline T. koningii 2.50 & $\begin{array}{c}0.0^{\mathrm{c}} \\
(0.0)^{\mathrm{D}}\end{array}$ & $\begin{array}{c}0.031^{\mathrm{b}} \\
(0.301)^{\mathrm{B}}\end{array}$ & $\begin{array}{c}0.003^{\mathrm{a}} \\
(0.031)^{\mathrm{A}}\end{array}$ \\
\hline P. funiculosum 1.6 & $\begin{array}{c}0.054^{\mathrm{ad}} \\
(0.866)^{\mathrm{AD}}\end{array}$ & $\begin{array}{c}0.002^{\mathrm{a}} \\
(0.029)^{\mathrm{A}}\end{array}$ & $\begin{array}{c}0.001^{\mathrm{a}} \\
(0.017)^{\mathrm{A}}\end{array}$ \\
\hline Penicillium spp. 2.33 & $\begin{array}{c}0.008^{\mathrm{c}} \\
(0,064)^{\mathrm{D}}\end{array}$ & $\begin{array}{c}0.001^{\mathrm{a}} \\
(0.002)^{\mathrm{A}}\end{array}$ & $\begin{array}{c}0.0^{\mathrm{a}} \\
(0.0)^{\mathrm{A}}\end{array}$ \\
\hline A. nidulans 1.13 & $\begin{array}{c}0.127^{\mathrm{b}} \\
(1.383)^{\mathrm{AB}}\end{array}$ & $\begin{array}{c}0.012^{\mathrm{ac}} \\
(0.122)^{\mathrm{AD}}\end{array}$ & $\begin{array}{c}0.002^{\mathrm{a}} \\
(0.006)^{\mathrm{A}}\end{array}$ \\
\hline T. koningii 2.47 & $\begin{array}{c}0.090^{\mathrm{ab}} \\
(1.148)^{\mathrm{A}}\end{array}$ & $\begin{array}{c}0.017^{\mathrm{bc}} \\
(0.226)^{\mathrm{BD}}\end{array}$ & $\begin{array}{c}0.001^{\mathrm{a}} \\
(0.014)^{\mathrm{A}}\end{array}$ \\
\hline Penicillium spp. 2.29 & $\begin{array}{c}0.012^{\mathrm{dc}} \\
(0.171)^{\mathrm{D}}\end{array}$ & $\begin{array}{c}0.001^{\mathrm{a}} \\
(0.012)^{\mathrm{A}}\end{array}$ & $\begin{array}{c}0.001^{\mathrm{a}} \\
(0.004)^{\mathrm{A}}\end{array}$ \\
\hline \multicolumn{4}{|c|}{ Group 2} \\
\hline A. nidulans 1.7 & $\begin{array}{c}0.024^{\mathrm{c}} \\
(0.211)^{\mathrm{C}}\end{array}$ & $\begin{array}{c}0.001^{\mathrm{bc}} \\
(0.006)^{\mathrm{B}}\end{array}$ & $\begin{array}{c}0.001^{\mathrm{a}} \\
(0.004)^{\mathrm{ABC}}\end{array}$ \\
\hline $\mathrm{X} 1.62$ & $\begin{array}{c}0.002^{\mathrm{b}} \\
(0.148)^{\mathrm{C}}\end{array}$ & $\begin{array}{c}0.001^{\mathrm{b}} \\
(0.022)^{\mathrm{B}}\end{array}$ & $\begin{array}{c}0.0^{\mathrm{c}} \\
(0.0)^{\mathrm{C}}\end{array}$ \\
\hline A. fumigatus 2.20 & $\begin{array}{c}0.004^{\mathrm{b}} \\
(0.040)^{\mathrm{D}}\end{array}$ & $\begin{array}{c}0.001^{\mathrm{b}} \\
(0.005)^{\mathrm{B}}\end{array}$ & $\begin{array}{c}0.0^{\mathrm{c}} \\
(0.0)^{\mathrm{C}}\end{array}$ \\
\hline P. funiculosum 1.6 & $\begin{array}{c}0.054^{\mathrm{a}} \\
(0.866)^{\mathrm{B}}\end{array}$ & $\begin{array}{c}0.002^{\mathrm{b}} \\
(0.029)^{\mathrm{B}}\end{array}$ & $\begin{array}{c}0.001^{\mathrm{a}} \\
(0.017)^{\mathrm{B}}\end{array}$ \\
\hline Penicillium spp. 2.37 & $\begin{array}{c}0.002^{\mathrm{b}} \\
(0.019)^{\mathrm{D}}\end{array}$ & $\begin{array}{c}0.009^{\mathrm{a}} \\
(0.108)^{\mathrm{A}}\end{array}$ & $\begin{array}{c}0.002^{\mathrm{b}} \\
(0.004)^{\mathrm{C}}\end{array}$ \\
\hline A. nidulans 1.28 & $\begin{array}{c}0.057^{\mathrm{a}} \\
(1.639)^{\mathrm{A}}\end{array}$ & $\begin{array}{c}0.0^{\mathrm{b}} \\
(0.0)^{\mathrm{B}}\end{array}$ & $\begin{array}{c}0.001^{\mathrm{a}} \\
(0.026)^{\mathrm{A}}\end{array}$ \\
\hline
\end{tabular}

The mean values given in columns with different letter index are significantly different $(\alpha<0.05)$; Significant differences were determined separately for group 1 and group 2; Homogeneous groups (with irrelevant differences inside) of the enzymatic activity expressed in (IU/ml) are marked with the small letter; Homogeneous groups (with irrelevant differences inside) of the enzymatic activity expressed (IU/mg of protein) are marked with the same capital letter

maximum EI values (from 4.0 to 6.0 ) did not reach their highest levels. The highest CMCase activity was reported for Trichoderma spp. isolates for which no EI values could be estimated as their colonies had no hydrolysis zones. Similar differences were observed by Jahangeer et al. (2005) who showed that the largest cellulose hydrolysis zone (18 $\mathrm{mm}$ for $A$. niveus) was not associated with the highest endoglucanase activity (CMCase activity for $A$. niveus was $0.276 \mathrm{IU} / \mathrm{ml}$ ).

This study did not show any correlation between EI values and the analyzed quantitative parameter (the amount of RS produced on a medium with $1 \% \mathrm{CMC}$ ), when all 90 isolates of different taxa were analyzed $(r=0.028$, Fig. 1).

In this study an attempt was made to establish the relationship between semiquantitative and quantitative methods for selected groups of fungi described as yeastlike fungi (Goldbeck et al., 2012) or for fungi belonging to only one genus (Florencio et al., 2012). According to Goldbeck et al. (2012), EI is not a suitable parameter for predicting the enzymatic features of 390 isolates. Five isolates of yeast-like fungi (out of 390) with EI values 


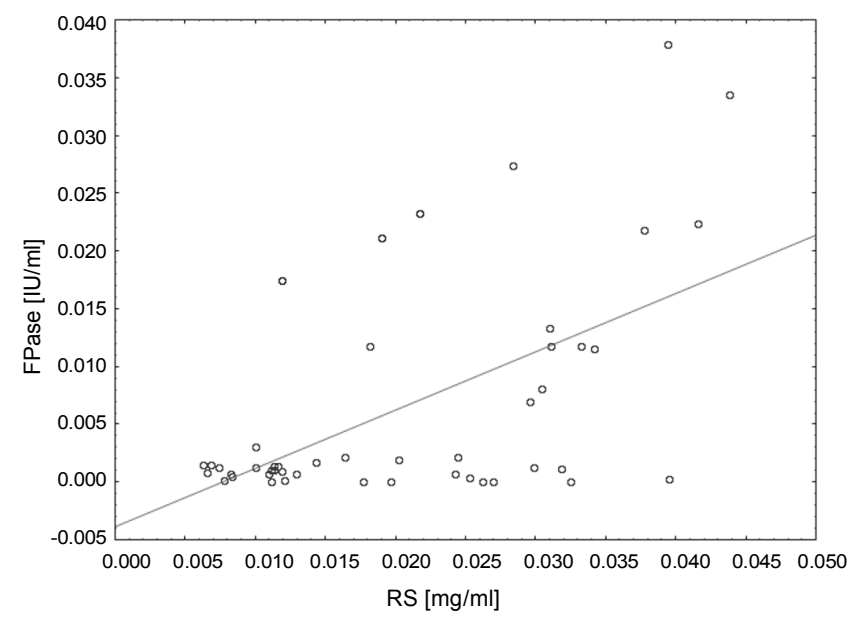

Fig. 2. Correlation between RS values (mg/g of CMC) and FPase activity $(\mathrm{IU} / \mathrm{ml})$ for groups 1 and $2(r=0.574)$

from 5.5 to 12.46 were chosen in a multi-stage selection. The highest endoglucanase and FPase activities were determined for Acremonium strictum AAJ6 (EI = 6.5). Florencio et al. (2012) analyzed the relationship between semiquantitative and quantitative methods in the genus Trichoderma $(n=78)$. They reported a high correlation $(r=0.977)$ for three native isolates with $\mathrm{EI}>1.0$ and endoglucanase activity $>0.2 \mathrm{IU} / \mathrm{ml}$ (reached in fermentation test in tubes) and activity in the range 17.9$32.8 \mathrm{IU} / \mathrm{g}$ (reached in solid-state fermentation). Such a correlation was not observed for an extended sample of 11 isolates grown on Whatman No. 1 filter paper.

Our study differentiates/distinguishes/indicates that there is no correlation between EI values and the analyzed quantitative parameter, when isolates belonged to genus Trichoderma $(n=16)$ or only to Penicillium genus $(n=26)(r=-0.007$ and $r=0.171$, respectively, data not shown). However, a positive average correlation between EI and RS ( $r=0.312)$, only in the group of fungi belonging to species Aspergillus fumigatus ( $n=15$ ), was proved. Filamentous fungi differ in the number of genes encoding the same type of cellulolytic enzymes. For example, Trichoderma reesei RUTC-30 has 3 BGL ( $\beta$-Dglucosidase glucohydrolase), 2 EG (1,4- $\beta$-D-glucan glucanohydrolases), and $2 \mathrm{CBH}$ (cellobiohydrolases) encoding genes. Another strain, Penicillium chrysogenum Wisconsin (13), has $17 \mathrm{BGL}, 12 \mathrm{EG}$, and $3 \mathrm{CBH}$ encoding genes (François and Guais, 2011). It is the reason why an analysis of the correlation between quantitative and semiquantitative methods should be carried out at the level of species.
Table 3. Pearson correlation coefficients for quantitative parameters and semiquantitative parameter (EI) for two selected groups of isolates

\begin{tabular}{l|c|c|c}
\hline & EI & $\begin{array}{c}\text { RS } \\
(\mathrm{mg} / \mathrm{g} \text { of CMC) }\end{array}$ & DV (\%) \\
\hline FPase $(\mathrm{IU} / \mathrm{ml})$ & $-0.342^{\mathrm{a}}$ & $0.574^{\mathrm{a}}$ & $0.553^{\mathrm{a}}$ \\
\hline CMCase $(\mathrm{IU} / \mathrm{ml})$ & -0.081 & 0.236 & 0.246 \\
\hline $\mathrm{CBase}(\mathrm{IU} / \mathrm{ml})$ & -0.020 & 0.278 & 0.236 \\
\hline $\mathrm{RS}(\mathrm{mg} / \mathrm{g}$ of CMC) & -0.262 & - & $0.779^{\mathrm{a}}$ \\
\hline DV $(\%)$ & -0.264 & $0.779^{\mathrm{a}}$ & - \\
\hline
\end{tabular}

\section{Correlation between semiquantitative and quantitative methods for 12 isolates}

A positive correlation between EI and RS was obtained only for a subset of isolates with either the highest EI values or the highest RS levels. So groups of isolates were selected based on that and a high correlation was found between RS, DV, and FPase. The correlation between EI and FPase was negative and was less clearly marked. It can therefore be concluded that the RS parameter can be useful in the selection of cellulolytic strains from a wide spectrum of filamentous fungi.

\section{Cellulase activity level}

In this work, the activity of FPase, CMCase, and CBase was evaluated for selected groups of filamentous fungi grown on $\mathrm{SmF}$ medium supplemented with CMC. The first group consisted of isolates with the highest amounts of reducing sugars (from 61 to $77 \mathrm{mg} / \mathrm{g}$ of $\mathrm{CMC}$ ). The second group consisted of isolates with the highest EI values (from 2.30 to 4.04).

The highest CMCase activity, $0.197 \mathrm{IU} / \mathrm{ml}$, was observed for Trichoderma isolate 1.12. A similar activity range, i.e., $0.22-0.27 \mathrm{IU} / \mathrm{ml}$, was reported by Florencio et al. (2012) for three native isolates of Trichoderma grown on a medium with filter paper. The activity of endoglucanase determined by Goldbeck et al. (2012) for A. strictum grown on Servacel was $0.33 \mathrm{IU} / \mathrm{ml}$. Jahangeer et al. (2005) reported maximum endoglucanase activities for various isolates, which ranged from 0.552 to $0.276 \mathrm{IU} / \mathrm{ml}$. However, maximum CMCase activity values obtained for Trichoderma sp. by Ruegger and Tauk-Tornisielo (2012) varied from 1.64 to $1.07 \mathrm{IU} / \mathrm{ml}$ (EI could not be determined, because of the lack of hydrolysis zone) and differed dramatically from the figures reported in the present paper. Maximum endoglucanase activities determined by Damaso et al. (2012) also belonged to the interval 3.0-15.1 IU/ml. 
Maximum FPase values determined in this study, $0.031 \mathrm{IU} / \mathrm{ml}(0.301 \mathrm{UL} / \mathrm{mg}$ of protein), were observed for Trichoderma isolate 2.50. Despite different cellulose type applied, the figures were similar to those obtained by other authors. Ruegger and Tauk-Tornisielo (2012) reported FPase values from 0.021 to $0.023 \mu \mathrm{mol}$ of glucose $/ \mathrm{ml} / \mathrm{min}$ for liquid cultures on Whatman No. 1 filter paper. Goldbeck et al. (2012) reported the value of $0.039 \mathrm{U} / \mathrm{ml}$ for cultures grown on microcrystalline cellulose Servacel. However, FPase values determined by Damaso et al. (2012) were much higher: $0.41 \mathrm{U} / \mathrm{ml}$ for an A. niger mutant and $45 \mathrm{U} / \mathrm{ml}$ for Aspergillus spp. grown on wheat bran.

In this study, two filamentous fungi strains belonging to Trichoderma species, called 1.12 and 2.50, were selected and will be applied in the future work on the acquisition of cellulolytic enzymes.

\section{Conclusion}

Semiquantitative methods (EI parameters) cannot be used for effective selection of different taxon of filamentous fungi capable of secreting endoglucanase (CMCase). EI parameters can be used for the selection of fungi showing an elevated total cellulolytic activity (FPase).

The amount of reducing sugars (RS), a quantitative parameter, as well as the decrease in the viscosity of the culture extract enable an effective selection of fungi with an elevated total cellulolytic activity.

\section{References}

Ahmed S., Bashir A., Saleem H., Saadia M., Jamil A. (2009) Production and purification of cellulose degrading enzymes from a filamentous fungus Trichoderma harzianum. Pak. J. Bot. 41 (3): 1411-1419.

Alvira P., Tomás-Pejó E., Ballesteros M., Negro M.J. (2010) Pretreatment technologies for an efficient bioethanol production process based on enzymatic hydrolysis - an overview. Bioresource Technol. 101: 4851-4861.

Bhat M.K. (2000) Cellulases and related enzymes in biotechnology. Biotechnol. Adv. 18: 355-383.

Bradford M.M. (1976) A rapid and sensitive method for the quantitation of microgram quantities of protein utilizing the principle of protein dye binding. Anal. Biochem. 72: 248-254.

Cherry J.R., Fidantsef A.L. (2003) Directed evolution of industrial enzymes: an update. Curr. Opin. Biotechnol. 14: 438-443

Crous P.W., Verkley G.J.M., Groenewald J.Z., Samson R.A. (2009) Fungal biodiversity. CBS-KNAW Fungal Biodiversity Centre, Utrecht, Netherlands.
Damaso M.C.T., da Costa Terzi S., Farias A.X., Pereira de Oliveira A.C., Fraga M.E., Couri S. (2012) Selection of cellulolytic fungi isolated from diverse substrates. Braz. Arch. Biol. Techn. 55 (4): 513-520.

Fassatiova O. (1983) Filamentous fungi in technical microbiology (in polish). Wyd. Naukowo-Techniczne, Warsaw, Poland.

Florencio C., Couri S., Farinas C.S. (2012) Correlation between agar plate screening and solid-state fermentation for the prediction of cellulase production by Trichoderma strains. Enzyme Res., 1-7.

François J.M., Guais O. (2011) Genomic and proteomic analyses provide insights into the potential of filamentous fungi for biomass degradation. In: Mycofactories. Ed. Leitão A.L., Portugal: Bentham Science Publishers: 45-56.

Ghose T.K. (1987) Measurement of cellulose activities. Pure \& App. Chem. 59(2): 257-268.

Goldbeck R., Andrade C.C.P., Pereira G.A.G., Filho M. (2012) Screening and identification of cellulase producing yeastlike microorganisms from Brazilian biomes. Afr. J. Biotechnol. 11(53): 11595-11603.

Huggett A.S.C., Nixon D.A. (1955) Glucose oxidase method for measurement of glucose. Biochem. J. 66: 12-19.

Ishikawa Y., Saka S. (2001) Chemical conversion of cellulose as treated in supercritical methanol. Cellulose 8: 189-195.

Jahangeer S., Khan N., Jahangeer S., Sohail M., Shahzad S., Ahmed A. (2005) Screening and characterization of fungal cellulases isolated from the native environmental source. Pak. J. Bot. 37(3): 739-748.

Kuhad R.C., Gupta R., Singh A. (2011) Microbial cellulases and their industrial applications. Enzyme Res. 1-10.

Kwaśna H., Chełkowski J., Zajkowski P. (1991) Fungi, vol. 22 - in polish. PAN, Warszawa-Kraków, Poland.

Lopes F., Motta F., Andrade C.C.P., Rodrigues M.I., MaugeriFilho F. (2011) Thermo-stable xylanases from non conventional yeasts. J. Microbial. Biochem. Technol. 3(3): 36-42.

Miller G.L. (1956) Use of dinitrosalicylic acid reagent for determination of reducing sugar. Anal. Chem. 1: 426-428.

Pérez J., Munoz-Moraleda A. (2011) Fungal ligninocellulolytic enzymes: applications in biodegradation and bioconversion. In: Mycofactories. Ed Leitão A.L., Portugal: Bentham Sci. Publ.: 28-44.

Ruegger M.J.S., Tauk-Tornisielo S.M. (2004) Cellulase activity of fungi isolated from soil of the Ecological Station of Juréia-Itatins, São Paulo, Brazil. Brazil. J. Bot. 27: 205211.

Russel S., Górska E.B., Wyczółkowski A.I. (2005) Enzymes taking part in hydrolysis of cellulose. Acta Agrophysica 3: 27-36.

Samson R.A., Frisvad J.C. (2004) Penicillium subgenus Penicillium: new taxonomic schemes and mycotoxins and other extrolites. Stud. Mycol. 449: 1-174.

Sazci A., Erenler K., Radford A. (1986) Detection of cellulolytic fungi by using Congo red as an indicator: a comparative study with the dinitrosalicylic acid reagent method. J. Appl. Bacteriol. 61(6): 559-562. 
Shuangqi T., Zhenyu W., Ziluan F., Lili Z., Jichang W. (2011) Determination methods of cellulase activity. Afr. J. Biotechnol. 10(37): 7122-7125.

Sun Y., Cheng J. (2002) Hydrolysis of lignocellulosic materials for ethanol production-an overview. Bioresour. Technol. 83: $1-11$.

Teather R., Wood P. (1982) Use of Congo Red-polysaccharide interactions in enumeration and characterization of cel- lulolytic bacteria from the bovine rumen. Appl. Environ. Microb. 43(4): 777-780.

Zhang Y.-H.P., Himmel M.E., Mielenz J.R. (2006) Outlook for cellulase improvement: screening and selection strategies. Biotechnol. Adv. 24: 452-481. 